International Journal of Advanced Biological and Biomedical Research Available online at http:www.ijabbr.com

Volume 8, Issue 1 (2020) pp. 17-28

DOI: 10.33945/SAMI/IJABBR.2020.1.3

Original Article

\title{
Kinetic Studies with Crude Wild Pear Lipoxygenase at During Ripening and After Storage
}

\section{Shahriar Saeidian ${ }^{1, *}$, Bahaaldin Rashidzadeh ${ }^{2}$, Roza Negahdari ${ }^{3}$}

\author{
${ }^{1}$ Assistant professor of Biochemistry, Payame Noor university, Tehran, Iran \\ ${ }^{2}$ Assistant professor of Chemistry, Payame Noor university, Tehran, Iran \\ ${ }^{3}$ MS.C of Chemistry, Payame Noor university, Tehran, Iran \\ *Corresponding Author E-mail: saeedyan@pnu.ac.ir
}

Received: 03 June 2019, Revised: 6 August 2019, Accepted: 11 August 2019

\begin{abstract}
Crude wild pear lipoxygenase (LOX) from ripe Kurdistan wild pears was used in this study. Extracted crude LOX was assayed spectrophotometrically for raw, ripe wild pear lipoxygenase and after 7 day storage. The effects of different buffers and pHs, substrate preparations, temperature, inhibitors and metal ions on LOX activity were evaluated at three conditions. The enzyme was most active with Hcl-Tris buffer at a $\mathrm{pH}$ of 7.5 and a temperature of $40{ }^{\circ} \mathrm{C}$. The best substrate was the first preparation with linoleic acid/Tween 20 at a ratio of $1: 1$. The kinetic parameters determined under the best conditions were a $\mathrm{Km}$ of $6.5 \mathrm{mM}$ and a $\mathrm{V}_{\max }$ of $0.9 \mathrm{unit} / \mathrm{mg}$ protein for raw condition, $5.8 \mathrm{mM}$ and a $V_{\max }$ of $0.95 \mathrm{unit} / \mathrm{mg}$ protein for ripe condition and $5 \mathrm{mM}$ and a $V_{\max }$ of 1.1 unit/mg protein obtained after storage. The enzyme was heat-labile. It was shown that crude wild pear LOX is fully active at room temperature $\left(20-30{ }^{\circ} \mathrm{C}\right)$, while the best activity occurred at $35^{\circ} \mathrm{C}$ for Lox after storage that activity of lipoxygenase increased up to $130 \%$. The results showed that lipoxygenase inhibitory activity of chemical compounds and standard compound decreased in the order of ascorbic acid $>$ nicotinic acid $>$ benzoic acid $>$ DL- $\alpha$-tocopherol. Monovalent and trivalent ions are inhibitors of LOX and divalent ions except $\mathrm{Zn}_{\mathrm{n}} \mathrm{Cl}_{2}$ are activators of LOX.
\end{abstract}

Key words: Wild pear, Lipoxygenase, Crude, Kinetics, Substrate.

\section{Introduction}

Lipoxygenase (LOX, EC 1.13.11.12) are a group of enzymes that catalyze dioxygenation of fatty acids by use of molecular oxygen which contains one or more 1,4(Z)-pentadiene systems, yielding chiral (E, Z) conjugated hydroxy fatty acids (Veldink et al., 1998; Riley et al., 1996). Lipoxygenase does the dioxygenation of unsaturated fatty acids, yielding a hydroperoxy fatty acid product. The physiological role of lipoxygenase in plants is not clear, but its function is in wounding and other stress responses (Rosahl, 1996). Lipoxygenase activity is additionally the primary step within the pathway resulting in the formation of a variety of flavor and aroma compounds and has been shown to contribute to the development of off flavors in several vegetables throughout frozen storage (Barrett and Theerakulkait, 1995). Multiple isozymes of lipooxygenase exist in many tissues of plants that have differences in regiospecificity, $\mathrm{pH}$ 
optimum, pI and enzymic properties. These isoenzymes have a single polypeptide chain with nearly 850 amino acids and an average of $96 \mathrm{kDa}$ molecular weight (Grechkin, 1998). Metabolites of unsaturated fatty acids have a function in growth and development, plant senescence and response to diseases and wounding., LOX in fruits have a role in the formation of volatile flavor compounds (Veldink et al., 1998; Riley et al., 1996; Ealing, 1994). LOX activity in wild pear fruits was interfered both in membraneous systems (Thompson et al., 1990; Riley et al., 1996) and insoluble form (Ealing, 1994; Veldink et al., 1998). Enzyme activity has been assayed by colorimetric, manometric, polarographic, spectrophotometric and radiolabeled substrate monitoring assays (Thompson et al., 1990; Surrey, 1964; Riley et al., 1996; Veldink et al., 1998). Values of $\mathrm{Km}$ and $\mathrm{V}_{\max }$ vary due to purity and assay differences (Thompson et al., 1990; Veldink et al., 1998). Product analysis has revealed a 96\% product specificity of 9-S-hydroperoxy-trans-10, cis-12-octadecanoic acid (9S-HPOD) formation from linoleic acid with an $82 \% \mathrm{~S}$ enantiomeric excess. The 13-HPOD formation was $1 \%$ and racemic (Veldink et al., 1998). In the present study, crude wild pear LOX was used to investigate the effect of different substrate forms and assay buffers on enzyme activity and also the thermal stability of the enzyme.

\section{Materials and methods}

Raw wild pears and ripe wild pears of the cultivar Kurdistan were harvested and transported to the University of payame Noor, Kurdistan, on the same day for the study. Some of the ripe wild pears were stored (7 days) at room temperature $\left(25^{\circ} \mathrm{C}\right)$ to a table ripe stage before homogenizing. Tween 20, linoleic acid, $\mathrm{MgCl}_{2}$, PVPP (polyvinylpyrrolidone), PMSF (phenylmethylsulfonyl fluoride) were purchased from Sigma Chem. Co. Tris N[Tris(hydroxymethyl) methyl]glycine, MES morpholinoethane sulfonic acid), EPPS (N-2Hydroxyethylpiperazine-NÕ-3-propane sulfonic acid), MOPS (3-(N-Morpholino)propane sulfonic acid), Hepes (N-2-Hydroxyethylpiperazine-NÕ-2-ethane sulfonic acid) and sodium acetate were purchased from Aldrich Chem. Co.

Enzyme extraction: Wild pears were washed with water and distilled water. After cutting the endocarp, some thick rings were separated transversely from each fruit. Slices were dipped in a potassium phosphate buffer $(50 \mathrm{mM})$ with a $\mathrm{pH}$ of 7.0 . To preventing from tissue browning, $0.1 \%$ ascorbate was added. For analyzing mesocarp fractions, the epicarp was physically separated. A total of $500 \mathrm{~g}$ of pears at raw, ripe and after storage were blended by a milling process, separately. The seed flour was mixed with $800 \mathrm{~mL}$ of $50 \mathrm{mM}$ sodium phosphate buffer, $\mathrm{pH}$ 7.5. The crude homogenate was subjected to mechanical stirring at $4{ }^{\circ} \mathrm{C}$ for $1 \mathrm{~h}$ sonicated using five pulses $(30 \mathrm{~S}$ each) of a sonicator (Qsonica, LLC series XL-2000, USA), set at the power setting $5 \mathrm{~W}$. Later, the homogenate was filtered through four layers of cheesecloths. The resulting suspension was centrifuged at 7,000 $\times \mathrm{g}$ for $20 \mathrm{~min}$. The pellet was discarded and the supernatant further treated with solid ammonium sulfate up to $60 \%$ of saturation and then the inactive supernatant eliminated by centrifugation at 7,000 $\times \mathrm{g}$ for $20 \mathrm{~min}$. The resulting precipitate was resuspended in a minimal amount of sodium phosphate buffer solution $(50 \mathrm{mM} \mathrm{pH} \mathrm{7.5)} \mathrm{dialyzed} \mathrm{twice} \mathrm{against}$ the same buffer for $20 \mathrm{~h}$ at $4{ }^{\circ} \mathrm{C}$. The dialyzed extract was assayed for protein content by Bradford's method. Bovine serum albumin (BSA) was used as the standard. The homogenate was used for evaluation of the activity of lipoxygenase of raw wild pear (RW-LOX), ripe wild pear (RPLOX) and LOX activity of wild pear after storage (ST-LOX).

Protein determination: The Bradford protein assay is used to measure the concentration of total protein of LOX (1976). The calibration curve was determined with IgG (bovine plasma gamma 
globulin) as the standard.

pHoptimum: The optimum pH of 6.5 used for linoleic acid and linolenic acid. The optimum pH of LOX of other sources is in a wide $\mathrm{pH}$ range from 5.5 to 9.5. $\mathrm{pH}$ optimum was determined in the presence of $0.1 \mathrm{M}$ acetate buffer and at different pHs of the solutions (Elez-Martínez et al., 2005; Marcus et al., 1988; Jacobo-Velázquez et al., 2010; Robinson et al., 1995).

Temperature optimum: Effects of temperature $\left(20-75{ }^{\circ} \mathrm{C}\right)$ on LOX activities were also determined. Given that wild pear grows in moderate and mild climates, a temperature optimum for LOX activity between $30^{\circ} \mathrm{C}$ and $40{ }^{\circ} \mathrm{C}$, as the one found in the present work, was expected. Since thermal processing or long exposure to high temperatures is likely to promote undesirable organoleptic changes in wild pear, the use of high temperature is an effective strategy to partially inactivate LOX.

Preparation of substrate: preparation of Linoleic acid as substrate was done in three different forms. At first, $0.5 \mathrm{~mL}$ of Tween 20 was dissolved in $10 \mathrm{~mL}$ of $0.1 \mathrm{M}$ Borate buffer with a pH of 9.0. Then $0.5 \mathrm{~mL}$ of linoleic acid was added simultaneously with mixing. Finally, $1.3 \mathrm{~mL}$ of $1 \mathrm{~N} \mathrm{NaOH}$ was added. So after minutes, a clear transparent solution was obtained. After that, $90 \mathrm{~mL}$ of Borate buffer was added until the total volume was reached to $200 \mathrm{~mL}$ with water. Preparation of the second substrate was done by dissolving an equal amount of linoleic acid $(0.5 \mathrm{~mL})$ in $200 \mathrm{~mL}$ of methanol without using detergent or buffer. For third preparation, $0.5 \mathrm{~mL}$ of linoleic acid was in presence of $20 \mathrm{~mL}$ of methanol added to a mixture of $180 \mathrm{~mL}$ of Borate buffer and Tween 20 with the same ratios. Also, for the first substrate preparation, the linoleic acid to Tween 20 ratio was evaluated $(1: 0,1: 1,1: 1.5$, and 1:2).

LOX assay: A jenway Spectrophotometer with 190-820 nm range and $2 \mathrm{~nm}$ bandwidth was used for determining of LOX activity. The assay method was done according to (Riley et al., 1996). Increasing of absorbance at $234 \mathrm{~nm}$ was followed for $5 \mathrm{~min}$ at $25^{\circ} \mathrm{C}$ by addition of $1 \mathrm{~mL}$ substrate solution in a cuvette in the presence of $1 \mathrm{~mL}$ of the crude LOX extract and $1 \mathrm{~mL}$ of assay buffer. The buffer that used was Na-Acetate $(0.1 \mathrm{M})$ with $\mathrm{pH}$ of 5.0 ; MES $(150 \mathrm{mM})$ with pH of 6.0; MOPS $(50 \mathrm{mM})$ with $\mathrm{pH}$ of 7.0; Hepes-KOH $(0.2 \mathrm{mM})$ with $\mathrm{pH}$ of 7.5; EPPS-KOH $(150 \mathrm{mM})$ with $\mathrm{pH}$ of 8.0; Tris-HCl $(150 \mathrm{mM})$ with $\mathrm{pH}$ of 8.5 ; Borate $(0.1 \mathrm{M})$ with $\mathrm{pH}$ of 9.0 and Glycine-KOH $(50 \mathrm{mM})$ with $\mathrm{pH}$ of 9.6. Enzyme specific activity is the amount of enzyme-producing one unit change in absorbance in one minute. The same method of the assay was done with the first substrate preparation of 1:1.5 LA: Tween 20 ratio. So, the values of Vmax and Km were also determined with different concentrations of the substrate (1.6-72.4 mM).

Temperature activity and thermal stability determination: To determine the optimum temperature of LOX activity, the assay was carried out at a range of $25^{\circ} \mathrm{C}$ until $80^{\circ} \mathrm{C}$ in presence of Tris-HCL buffer ( $50 \mathrm{mM}, \mathrm{pH} 8.0$ ) and $5^{\circ} \mathrm{C}$ intervals. Thermal stability evaluated by incubation of enzyme solution in a water bath from $25^{\circ} \mathrm{C}$ to $80^{\circ} \mathrm{C}(30 \mathrm{~min})$ and in the following, the mixture was kept at room temperature $(10 \mathrm{~min})$. Eventually, the residual LOX activity was assayed. Experiments were done in triplicates. For half-life (t 1/2) determination, incubation of enzyme solution $\left(220 \mathrm{U} / \mathrm{mg}\right.$ ) was done up to $60 \mathrm{~min}$ in optimal conditions (temperatures of $25^{\circ} \mathrm{C}, 30^{\circ} \mathrm{C}$, $35^{\circ} \mathrm{C}, 40^{\circ} \mathrm{C}$, and $45^{\circ} \mathrm{C}$ ). For each $30 \mathrm{~min}$ interval, $20 \mu \mathrm{l}$ of the sample was taken to evaluating residual activity. The amount of activity at the onset of the assay was considered as $100 \%$. Finally, the results of residual activity were depicted against incubation time.

In vitro lipoxygenase-inhibitory assay: Assay for determination of inhibition of lipoxygenase activity was done and determined by a spectrophotometric method reported by (Yawer et al., 
2007). The reaction mixture for assay, containing inhibition solution and lipoxygenase solution in $0.1 \mathrm{M}$ phosphate buffer with a $\mathrm{pH}$ of 8.0. So they were incubated for $10 \mathrm{~min}$ at $25^{\circ} \mathrm{C}$. After that, the assay was initiated by addition substrate. The absorbance value was measured at $234 \mathrm{~nm}$ after $6 \mathrm{~min}$. was standard inhibitor that used in the assay was quercetin. The percent inhibition of lipoxygenase activity was evaluated by the equation of Inhibition $(\%)=(1-A / B) \times 100$, where A refers to enzyme activity without inhibitor and B is the activity in presence of inhibitor. The IC50 was determined as the concentration of LOX extracts required to inhibit lipoxygenase activity by $50 \%$.

Tissue localization of LOX activity: Crude enzyme extract was prepared from isolated pericarp tissue and used for all the above assays. Also, wild pear skin, locular gel material, and whole fruit were used to compare tissue activity distribution.

Statistical analysis: Statistical procedures were performed using the statistical analysis system (SAS Institute, Cary, NC). The effect of LOX specific activity by different substrate preparations was determined by ANOVA with means separation by DuncanÕs Multiple Range test. Regression analysis of the double-reciprocal plot determined the best-fitting straight line. All measurements were made twice and the result reported was the mean of the two. The level of significance was $5 \%$ for all tests.

Effect of metal ions on enzyme activity: To the investigation of effects of metal ions on lipoxygenase activity of RW-LOX, RP-LOX, and ST-LOX, some chemical compounds such as monovalent ion $(\mathrm{NaCl})$, Divalent ions $\left(\mathrm{Z}_{\mathrm{n}} \mathrm{Cl}_{2}, \mathrm{CaCl}_{2}, \mathrm{FeCl}_{2}\right.$, and $\left.\mathrm{MgCl}_{2}\right)$ and trivalent ion $\left(\mathrm{Fecl}_{3}\right)$ were selected. The applied concentrations at which these ions were prepared in $50 \mathrm{mM}$ Tris-HCL buffer at pH 7.5. Concentrations of metal ions that prepared were $0.1,0.5$ and $1 \mathrm{mM}$. Each mixture reaction was incubated at room temperature for $10 \mathrm{~min}$ and finally, the activity of RW-LOX, RPLOX, and ST-LOX was measured, separately. A mixture assay without metal ions was considered as $100 \%$ activity.

\section{Results and discussion}

In this research, the assay buffers evaluated. So, the Tris- $\mathrm{HCl}$ ( $\mathrm{pH} 7.5)$ was the best in terms of crude LOX specific activity (Figure 1). Buffers such as MOPS with a pH of 7.0 and MES buffer with $\mathrm{pH}$ of 6.0 were also suitable for the enzyme. On the other hand, Borate with a pH of 9.0 and Glycine-KOH with pH of 9.6 showed the lowest LOX activity. Optimal pH of 6.0-6.5 has been reported in several studies (Thomson et al., 1990; Lauriere et al., 1993; Ealing 1994). The reason for inappropriate Borate buffer as an inorganic buffer might be due to its $\mathrm{pH}$ (9.0). Between the five buffers that showed different $\mathrm{pH}$ values for the specific LOX activity (Figure 1), Tris- $\mathrm{HCl}$ buffer was chosen for the subsequent analyses.

The efficiency of the different substrate preparations for crude wild pear LOX is summarized in Table 1. The ratio of 1:1 linoleic acid: Tween 20 and 1:1 linolenic acid: Tween 20 ratio were the best of all evaluated, with the specific activity of 0.83 and 0.75 (Units/mg protein) value, respectively. It can be concluded from the results that when linoleic and linolenic acid can form micelles with sufficient amount of Tween 20, they are most suitable for the reaction, but very high or low concentrations of Tween 20 can cause problems in solubility and diffusion. 


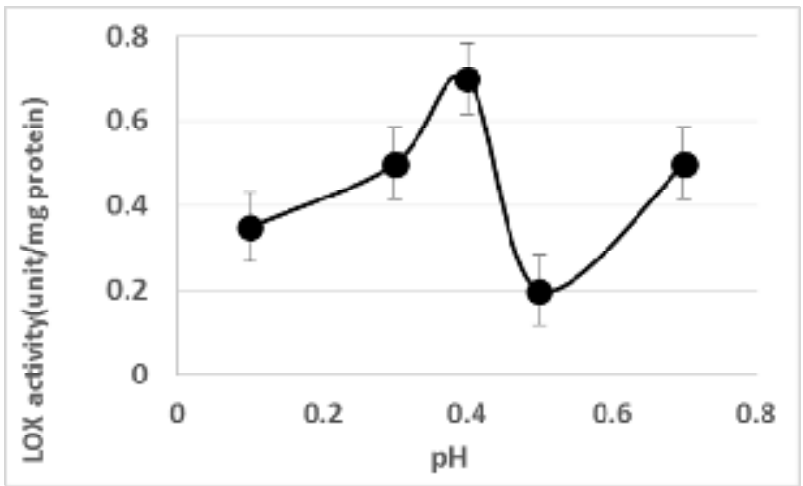

Figure 1. Effects of the different assay buffers (and pHs) on the activity of crude pear LOX

According to these results, preparation with the 1:1 linoleic acid: Tween 20 and linolenic acid: Tween 20 ratio was chosen for doing the analyses. Figure 2 shows the Michaelismenton plot of the crude wild pear lipoxygenase.

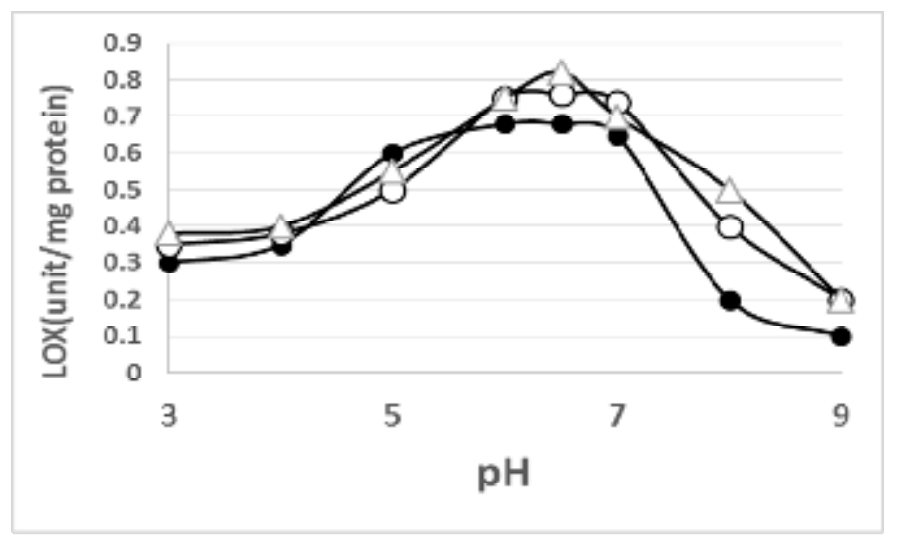

Figure 2. Effects of the different assay buffers (and pHs) on the activity of crude wild pear lipoxygenase. Linolenic acid (Immature $(\bullet)$, ripe $(0)$, after storage $(\Delta)$ ) in presence of linoleic acid:tween 20 as substrate

Table 1. Effect of substrate preparation methods on the crude wild pear LOX specific activity

\begin{tabular}{ccc}
\hline Substrate preparation & Ratio & LOX activity (unit/ mg protein) \\
\hline Linoleic acid : tween 20 & $1: 0$ & 0.72 \\
Linoleic acid : tween 20 & $1: 1$ & 0.83 \\
Linoleic acid : tween 20 & $1: 1.5$ & 0.79 \\
Linoleic acid : tween 20 & $1: 2$ & 0.75 \\
Linolenic acid : tween 20 & $1: 0$ & 0.61 \\
Linolenic acid : tween 20 & $1: 1$ & 0.75 \\
Linolenic acid : tween 20 & $1: 1.5$ & 0.62 \\
Linolenic acid : tween 20 & $1: 2$ & 0.58 \\
\hline
\end{tabular}

Analyzing of Data was done to determine the best fitting theoretical hyperbolic curve. The kinetic parameters were estimated from analyzing of data. so, the $\mathrm{K}_{\mathrm{m}}$ of the LOX obtained $6.5 \mathrm{mM}$ and $V_{\max }$ was obtained as 0.9 unit/mg protein in immature wild pear. The $K_{\mathrm{m}}$ in ripe wild pear was $5.8 \mathrm{mM}$ and $\mathrm{V}_{\max }$ was 0.95 unit/mg protein, although these parameters 
reached to $5 \mathrm{mM}$ and $1.1 \mathrm{unit} / \mathrm{mg}$ protein for $\mathrm{k}_{\mathrm{m}}$ and $\mathrm{V}_{\max }$ in wild pear after storage, respectively, in presence of linoleic acid as substrate (Table2).

Table 2. Kinetic parameters of lipoxygenase at raw, ripe and storage condition in presence of linoleic acid

\begin{tabular}{cccccc}
\hline Linoleic acid & \multicolumn{4}{c}{ Kinetics parameters } \\
& $\begin{array}{c}\mathbf{K}_{\mathbf{m}} \\
\text { (mM) }\end{array}$ & $\begin{array}{c}\text { Vmax } \\
\text { (unit/ mg) }\end{array}$ & $\begin{array}{c}\text { Catalytic } \\
\text { efficiency }\end{array}$ & $\begin{array}{c}\mathbf{p H} \\
\text { optimum }\end{array}$ & $\begin{array}{c}\text { Temperature } \\
\text { optimum }\end{array}$ \\
\hline Immature pear & 6.5 & 0.9 & 0.13 & 6.5 & $35^{\circ} \mathrm{C}$ \\
Ripe pear & 5.8 & 0.95 & 0.16 & 6.5 & $35^{\circ} \mathrm{C}$ \\
Pear after & 5 & 1.1 & 0.22 & 6.5 & $35{ }^{\circ} \mathrm{C}$ \\
storage & & & & & \\
\hline
\end{tabular}

The kinetic parameters were estimated in immature wild pear, ripe wild pear and pear after storage in presence of linolenic acid as the second substrate. So, the $K_{m}$ of the enzyme is 6.8 $\mathrm{mM}$ and $V_{\max }$ value of $0.81 \mathrm{unit} / \mathrm{mg}$ protein in immature wild pear and $\mathrm{K}_{\mathrm{m}}$ of the enzyme in ripe wild pear obtained $6.2 \mathrm{mM}$ and $\mathrm{V}_{\max }$ value of $0.92 \mathrm{unit} / \mathrm{mg}$ protein and these kinetic parameters in wild pear after storage reached $5.4 \mathrm{mM}$ and $0.99 \mathrm{unit} / \mathrm{mg}$ protein for $\mathrm{K}_{\mathrm{m}}$ and $V_{\text {max }}$, respectively (Table 3). Previous studies have reported $K_{m}$ values ranging from $0.015 \times$ $10^{-4} \mathrm{M}$ to $4.1 \mathrm{mM}$, and $\mathrm{V}_{\max }$ values ranging from $0.186 \mathrm{mM} / \mathrm{U}$ to $7.4 \mathrm{mM} / \mathrm{U}$ (Thompson et al., 1990; Veldink et al., 1998; Biacs and Daood 1987). The values vary with the level of enzyme purity and difference in assay method.

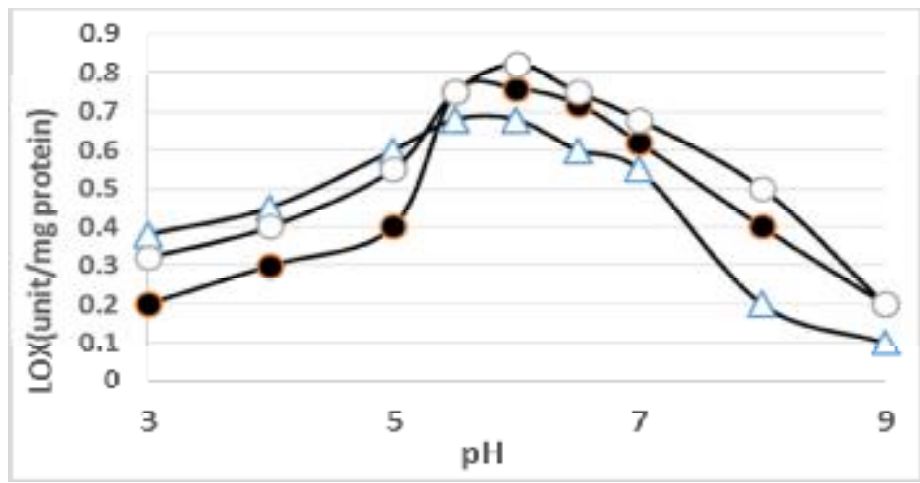

Figure 3. Effects of the different assay buffers (and pHs) on the activity of crude wild pear lipoxygenase. (Immature wild pear $(\bullet)$, ripe $(0)$, after storage $(\Delta)$ ) in presence of linolenic acid:tween 20 as substrate

Table 3. Kinetic parameters of lipoxygenase at raw, ripe and storage condition in presence of linolenic acid

\begin{tabular}{cccccc}
\hline Linolenic acid & \multicolumn{4}{c}{ Kinetics parameters } \\
& $\begin{array}{c}\mathbf{K}_{\mathbf{m}} \\
\text { (mM) }\end{array}$ & $\begin{array}{c}\mathbf{V}_{\mathbf{m a x}} \\
\text { (unit/ mg) }\end{array}$ & $\begin{array}{c}\text { Catalytic } \\
\text { efficiency }\end{array}$ & $\begin{array}{c}\mathbf{p H} \\
\text { optimum }\end{array}$ & $\begin{array}{c}\text { Temperature } \\
\text { optimum }\end{array}$ \\
\hline Immature pear & 6.8 & 0.81 & 0.11 & 6.5 & $35^{\circ} \mathrm{C}$ \\
Ripe pear & 6.2 & 0.92 & 0.14 & 6.5 & $35^{\circ} \mathrm{C}$ \\
Pear after & 5.4 & 0.99 & 0.18 & 6.5 & $35{ }^{\circ} \mathrm{C}$ \\
storage & & & & & \\
\hline
\end{tabular}


The assay of the enzyme in the form of crude was done with the buffer in optimum of $\mathrm{pH}$ and best substrate at room temperature. The heat stability of LOX at different temperatures is shown in Figure 4. At raw condition, crude lipoxygenase was rapidly inactivated at 70-80 ${ }^{\circ} \mathrm{C}$, and during 2-3 $\mathrm{min}$, the activity of enzyme reached to near zero. The enzyme was incubated at $70{ }^{\circ} \mathrm{C}$ for $1 \mathrm{~min}$, after that, only $20 \%$ of the initial activity was retained, but after 7 min incubation, all of the activity was lost. On the other hand, incubation for 2 min at $60{ }^{\circ} \mathrm{C}$ caused only $40 \%$ activity loss. At $5 \mathrm{~min}, 20 \%$ of the activity of LOX remained at the same temperature. The assay for ripe condition, crude lipoxygenase was rapidly inactivated at $80{ }^{\circ} \mathrm{C}$, and after 6-7 min, activity reached to near zero. Incubation of enzyme for $1 \mathrm{~min}$ at $70{ }^{\circ} \mathrm{C}$, so, $65 \%$ of the initial activity has remained, but after 7 min incubation, the activity was zero. On the other hand, after incubation for $2 \mathrm{~min}$ at $60{ }^{\circ} \mathrm{C}$, only $25 \%$ of activity missed. At $5 \mathrm{~min}$, however, only $40 \%$ of the activity remained at the same temperature.

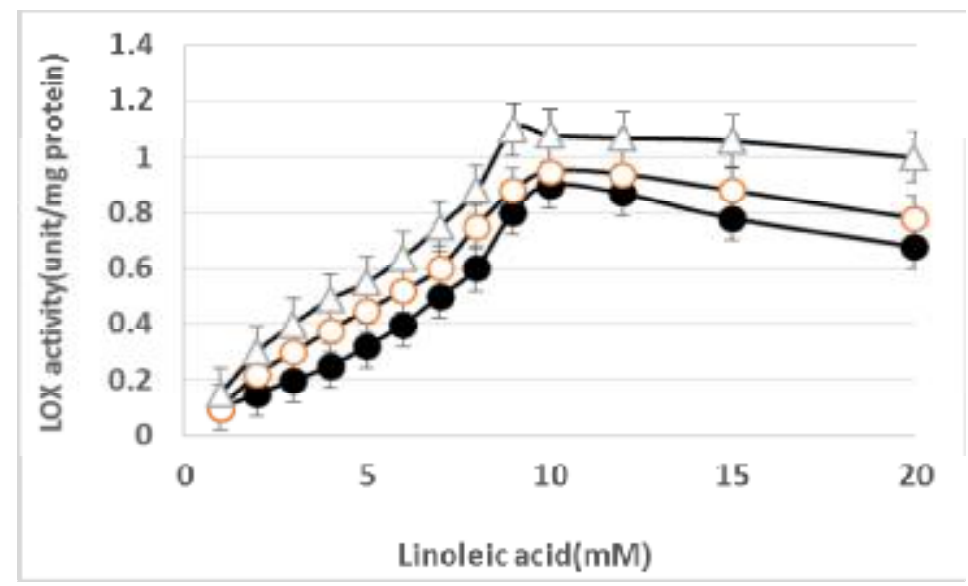

Figure 4. Michaelis-menton plot of crude Wild pear lipoxygenase with linoleic acid: tween 20 (1:1 ratio) as substrate and Tris- $\mathrm{HCl}(\mathrm{pH} 7.5)$

This assay was done for the condition that wild pear store for 7 days at room temperature. So, at this condition, crude lipoxygenase was inactivated at $80^{\circ} \mathrm{C}$ and in $6-7 \mathrm{~min}$ all activity reached to near zero. The enzyme was applied $1 \mathrm{~min}$ at $70{ }^{\circ} \mathrm{C}$ after $1 \mathrm{~min}$, so, $60 \%$ of the initial activity was retained, but when the time was increased to $7 \mathrm{~min}$, the activity was zero. On the other hand, putting on for $2 \mathrm{~min}$ at $60{ }^{\circ} \mathrm{C}$ caused only $15 \%$ activity loss. At 5 min, however, only $50 \%$ of the activity remained at the same temperature. The optimum temperature for the activity of RW-LOX, RP-LOX, and ST-LOX are shown in Figure 5. It was shown that crude wild pear LOX is fully active at room temperature $\left(20-30{ }^{\circ} \mathrm{C}\right)$, while the best activity occurred at $35{ }^{\circ} \mathrm{C}$ for Lox after storage that activity of lipoxygenase increased up to $130 \%$. At $40{ }^{\circ} \mathrm{C}$, the activity of LOX obtained at $100-110 \%$ and at $45^{\circ}-80{ }^{\circ} \mathrm{C}$, the activity of LOX decreased so, at $60^{\circ}$ reached to $60-70 \%$ and at $80{ }^{\circ} \mathrm{C}$ reached to zero. In conclusion, crude LOX is active at room temperature range and more activity obtained up to $40{ }^{\circ} \mathrm{C}$ where it naturally acts on substrates. By increasing the storage time, the thermal effect on the LOX structure led to less decrease in the enzyme activity in compare to RP-LOX and RP-LOX, so the stability of enzyme increased by increasing time of storage up to 7 days. The inhibitory properties of benzoic acid, ascorbic acid and nicotinic acid and DL- $\alpha$ tocopherol on pear lipoxygenase activity of RW-LOX, RP-LOX, and ST-LOX were compared 
using linoleic acid as a substrate. All of the compounds exhibited affinity to a substrateenzyme complex. Ascorbic acid was found to has the highest LOX inhibitory activity.
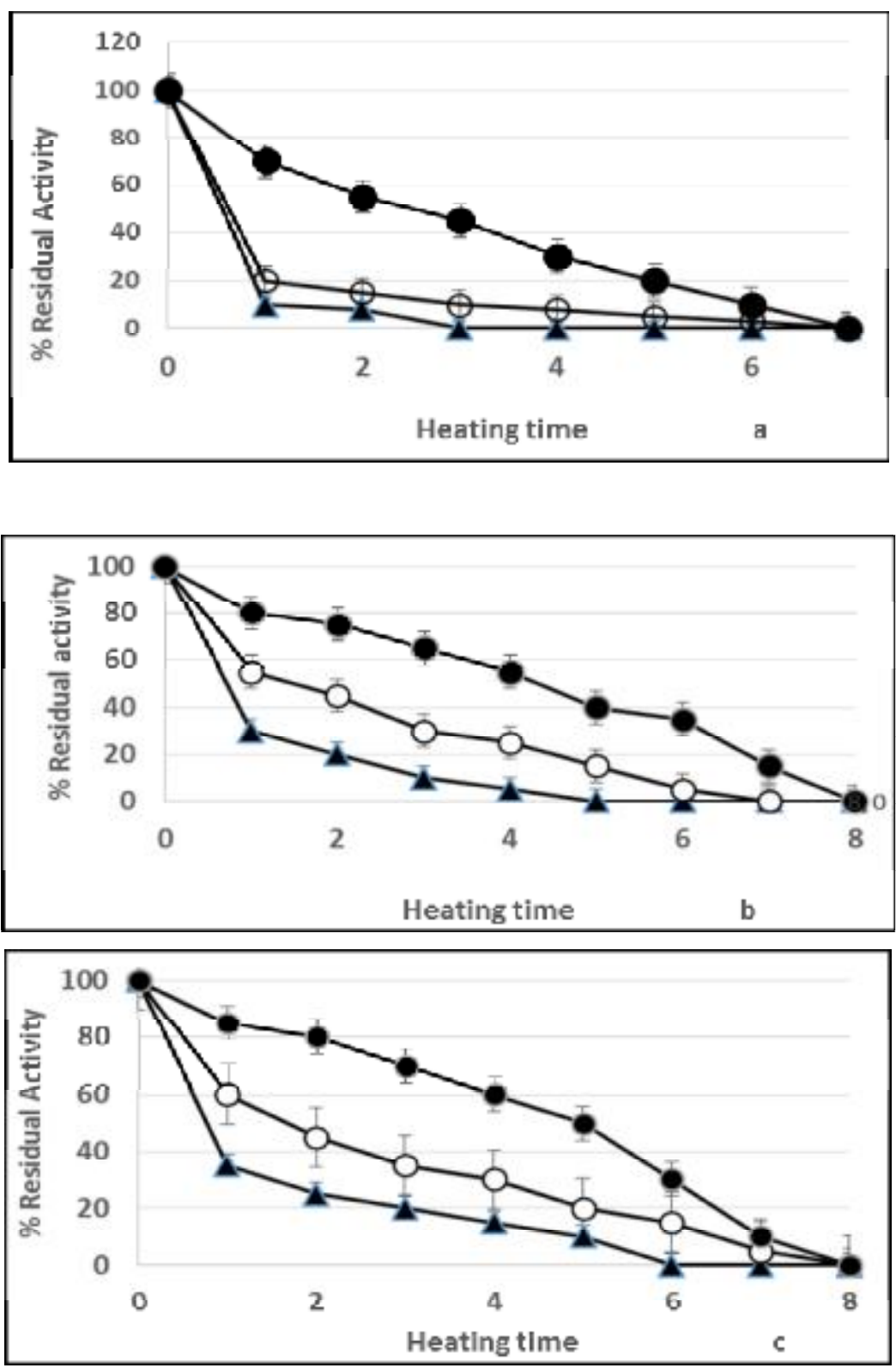

Figure 5. Thermal stability of crude lipoxygenade at Raw crude wile pear(a), Ripe crude wile pear (b) and after storage $(\mathrm{c}) \cdot\left(60^{\circ} \mathrm{C}(\bullet), 70^{\circ} \mathrm{C}(\mathrm{O})\right.$ and $80^{\circ} \mathrm{C}(\Delta)$

IC50 value was found $0.15,0.13$ and $0.11 \mathrm{mM}$ for RW-LOX, RP-LOX and ST-LOX, respectively.

DL- $\alpha$-tocopherol was found to have the lowest LOX inhibitor activity, 4.6, 4 and $3.7 \mathrm{mM}$ for RW-LOX, RP-LOX, and ST-LOX, respectively. Lipoxygenase inhibitory activity of chemical compounds and standard compound decreased in the order of ascorbic acid $>$ nicotinic acid> benzoic acid $>$ DL- $\alpha$-tocopherol (Table 4). Parallel lines were observed for inhibition of LOX by ascorbic acid in RW-LOX, RP-LOX, and ST-LOX. This acid showed the nature of 
uncompetitive inhibitors. benzoic acid and nicotinic acid and DL- $\alpha$-tocopherol were noncompetitive inhibitors. Since some metal ions are known to be required as coenzymes or as cofactors for various enzymes such as LOX, we tested the effects of various metal ions on the activity of RW-LOX, RP-LOX , and ST-LOX.

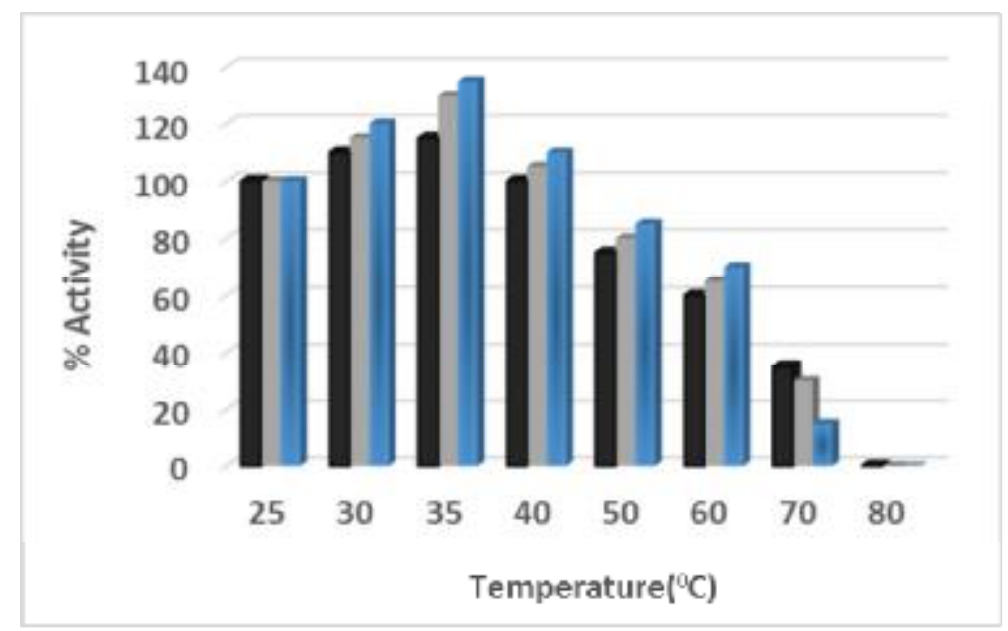

Figure 6. The optimum temperature for activity of lipoxygenase in presence of linoleic acid at Raw crude wile pear (a), Ripe crude wile pear (b), and after storage (c)

Each metal ion $(0.1,0.5$ and $1 \mathrm{mM})$ in the form of chloride salt was added to the assay mixture before the enzyme assay, separately. Our results about metal ions showed that Divalent ions such as $\mathrm{CaCl}_{2}, \mathrm{FeCl}_{2}$, and $\mathrm{MgCl}_{2}$ are activators of lipoxygenase, specifically at RW-LOX and RP-LOX. So, at $0.1 \mathrm{mM}$ of $\mathrm{CaCl}_{2}, \mathrm{FeCl}_{2}$ and $\mathrm{MgCl}_{2}$, the activity of LOX increased ,and reached 135, 148, and $128 \%$ in comparison to control (without metal ions). With increasing the concentrations of $\mathrm{CaCl}_{2}, \mathrm{FeCl}_{2}$, and $\mathrm{MgCl}_{2}$ up to 0.5 and $1 \mathrm{mM}$, LOX activity decreased, but their activities were upper than control. LOX activity of RW-LOX, RP-LOX and ST-LOX in presence of $0.1,0.5$ and $1 \mathrm{mM}$ of Nacl decreased, so for RW-LOX reached to 70,60 and 40\%, and for RP-LOX reached to 80, 71 and 55\% and for ST-LOX reached to 85, 76 and $62 \%$, respectively.

Table 4. Lipoxygenase inhibitory activity of some chemical compounds for lipoxygenase activity at raw, ripe and storage condition in presence of linoleic acid

\begin{tabular}{|c|c|c|c|}
\hline Inhibitors & Source & IC50 (mM) & Type of inhibition \\
\hline \multirow[t]{3}{*}{ Ascorbic acid } & Raw wile pear & 0.15 & un-competetive \\
\hline & Ripe wild pear & 0.13 & un-competetive \\
\hline & Wild pear after storage & 0.11 & un-competetive \\
\hline \multirow[t]{3}{*}{ Nicotinic acid } & Raw wile pear & 0.45 & non-competitive \\
\hline & Ripe wild pear & 0.42 & non-competitive \\
\hline & Wild pear after storage & 0.39 & non-competitive \\
\hline \multirow[t]{3}{*}{ Benzoic acid } & Raw wile pear & 3 & non-competitive \\
\hline & Ripe wild pear & 2.5 & non-competitive \\
\hline & Wild pear after storage & 2 & non-competitive \\
\hline \multirow[t]{3}{*}{ DL- $\alpha$-tocopherol } & Raw wile pear & 4.6 & non-competitive \\
\hline & Ripe wild pear & 4 & non-competitive \\
\hline & Wild pear after storage & 3.7 & non-competitive \\
\hline
\end{tabular}


Maximum of activity of lipoxygenase obtained for wild pear after storage in presence of $\mathrm{Fecl}_{2}(0.1 \mathrm{mM})$ and minimum of activity of lipoxygenase obtained for RW-LOX in presence of Nacl (1 mM). In according to our results, monovalent and trivalent ions are inhibitors of LOX and divalent ions except of $\mathrm{Zncl}_{2}$ are activators of LOX. The activation of lipoxygenase of wild pear in the presence of metal ions was in the order of $\mathrm{Fecl}_{2}>\mathrm{Cacl}_{2}>\mathrm{Zncl}_{2}>\mathrm{Nacl}>\mathrm{Fecl}_{3}$ and these activation was in order of ST-LOX $>$ RP-LOX $>$ RW-LOX. Other researchers confirmed our results, so, Soybean LOX activity has been inhibited by $\mathrm{Mg}^{2+}$ and $\mathrm{Mn}^{2+}$, whereas its activity was increased vigorously by Fecl 2 (Aberomand et al., 2013).

Table 5. Effect of metal ions on LOX activity at raw, ripe and conditions after storage of wild pear in presence of linoleic acid as substrate

\begin{tabular}{ccccc}
\hline Metal ions & Source & $\begin{array}{c}\text { Relative activity (\%) } \\
\text { Nacl (0.1 mM) }\end{array}$ & $\begin{array}{c}\text { Relative } \\
\text { activity (\%) } \\
\text { Nacl (0.5 mM) }\end{array}$ & $\begin{array}{c}\text { Relative } \\
\text { activity (\%) } \\
\text { Nacl (1 mM) }\end{array}$ \\
\hline \multirow{2}{*}{ Nacl } & Raw wild pear & 70 & 60 & 40 \\
& Ripe wild pear & 80 & 71 & 55 \\
Zncl $_{2}$ & Pear after storage & 85 & 76 & 62 \\
& Raw wild pear & 82 & 77 & 54 \\
& Ripe wild pear & 88 & 81 & 63 \\
$\mathrm{Cacl}_{2}$ & Pear after storage & 94 & 85 & 69 \\
& Raw wild pear & 135 & 115 & 92 \\
& Ripe wild pear & 146 & 122 & 98 \\
$\mathrm{Fecl}_{2}$ & Pear after storage & 155 & 136 & 108 \\
& Raw wild pear & 148 & 132 & 115 \\
$\mathrm{Mgcl}_{2}$ & Ripe wild pear & 161 & 148 & 122 \\
& Pear after storage & 168 & 151 & 134 \\
& Raw wild pear & 128 & 112 & 88 \\
$\mathrm{Fecl}_{3}$ & Ripe wild pear & 138 & 119 & 95 \\
& Pear after storage & 146 & 125 & 105 \\
& Raw wild pear & 58 & 46 & 38 \\
& Ripe wild pear & 68 & 55 & 43 \\
\hline
\end{tabular}

\section{Conclusion}

Genarally, crude of wild pear LOX is optimum at pH 6.0 in the MES buffer $\left(25^{\circ} \mathrm{C}\right)$. Similarly, the best substrate used was first preparation with linoleic acid and Tween 20 with proportion of 1:1.5. Assays of kinetic study of LOX revealed a $\mathrm{K}_{\mathrm{m}}$ with value of $4.198 \mathrm{mM}$ and a $V_{\max }$ with value of $0.84 \mathrm{mM} / \mathrm{min}$. The optimum of activity of LOX obtained at room temperature $\left(20-30^{\circ} \mathrm{C}\right)$. The activity of enzyme at $80^{\circ} \mathrm{C}$ after 2 min was diminished. Most of the activity was seen in the pericarp tissue. These results might be very useful while wild pear pericarp tissue is known as a LOX source in biotechnological applications. Among the studied metal ions, $\mathrm{Fecl}_{2}$ had the maximum effect on the RW-LOX, RP-LOX and ST-LOX activity at $0.1 \mathrm{mM}$ concentration, and, $\mathrm{Fecl}_{3}$ strongly decreased the LOX activity at the same concentration. Consequently, it seems that these ions have varying effects on the oxygenating activity of LOX or the binding of fatty acid substrate to the active site (MarvianHosseini and Asoodeh, 2017). At the concentration of $1.0 \mathrm{mM}, \mathrm{Zncl}_{2}$ inhibited enzyme activity of about $20 \%$ compared with the control. 


\section{Acknowledgment}

This work was supported by a grant from payame noor university at biochemistry department.

\section{References}

Aberomand, M, Kheirollah, A. Nikzamir, A. Malekasgar, AM, Alimohammadi, M. (2013). The Inhibitory Effect of KCN, NAN3 and Some Bivalent Ions on Lipoxygenase Activity of the Purified Human Placental, Iranian. J. Pharm. Sci., 9(1):39-45.

Barrett, DM, Theerakulkait, C. (1995). Quality indicators in blanched, frozen, stored vegetables. Food Technol., 49:62-65.

Biacs, PA., Daood, H., (1987). Characterization of tomato lipoxygenase. In: Stumpf PK, Mudd JB, Nes ND, eds. Metabolism, Structure, and Function of Plant Lipids , NY: Planum Press, pp. 425429.

Bradford, MM. (1976). A rapid and sensitive method for the quantitation of microgram quantities of protein utilizing the principle of proteindye binding. Anal. Biochem., 72:248-254.

Ealing, PM. (1994). Lipoxygenase activity in ripening tomato fruit pericarp tissue. Phytochem., 36:547-552.

Ealing PM . 1994.Lipoxygenase activity in ripening tomato fruit pericarp tissue.Phytochemistry36: 547-552.

Elez-Martínez, P, Soliva-Fortuny, RC, Gorinstein, S, Martín-Belloso, O. (2005). Natural antioxidants preserve the lipid oxidative stability of minimally processed avocado purée. J. Food Sci., 70:325-329. FAOSTAT, FAO Statistical databases, agricultural data, 2008, http://faostat.fao.org.

Grechkin, A, (1998). Recent developments in biochemistry of the plant lipoxygenase pathway. Prog. Lipid Res., 37:317-352.

Lauriere, C, Droillard, MJ, Rouet-Mayer, MA, Bureau, JM. (1993). Membrane-associated and soluble lipoxygenase isoforms in wild pear pericarp. Plant Physiol., 103:1211-1219.

Jacobo-Velázquez, DA, Hernández-Brenes, C, Cisneros-Zevallos, L, Benavides, J. (2010). Partial purification and enzymatic characterization of avocado (Persea americana Mill, cv. Hass) lipoxygenase. Food Res. Int., 43:1079-1085.

Marcus, L, Prusky, D, Jacoby, B. (1988). Purification and characterization of avocado lipoxygenase, Phytochem., 27(2):323-327.

Marvian-Hosseini, Z, Asoodeh, A. (2017). Biochemical characterization of purified lipoxygenase from sesame (Sesamum indicum). Int.J. Food Propert., 20:S948-S958.

Riley, JCM, Willemot, C, Thompson, JE. (1996). Lipoxygenase and hydroperoxide lyase activities in ripening wild pear fruit. Postharvest Biol. Technol., 7:97-107. 
Robinson, DS, Wu, Z, Domoney, C, Casey, R. (1995). Lipoxygenases and the quality of foods. Food Chem., 54(1):33-43.

Rosahl, S. (1996). Lipoxygenases in plantss their role in development and stress responses. Z Naturforsch C., 51:123-138.

Surrey, K. (1964). Spectrophotometric method for determination of lipoxidase activity. Plant Physiol., 39:65-70.

Svendsen, A. (2004). Enzyme Functionality Design, Engineering, and Screening; Marcel Dekker, Inc:New York, USA.

Thompson, JE, Todd, JF, Paliyath, G. (1990). Characterization of a membrane-associated lipoxygenase in wild pear fruit. Plant Physiol., 94:1225-1232.

Veldink, GA, Suurmeijer, CNSP, Perez-Gilabert, M, van der Hijden, HTWM, Vliegenthart, JFG. (1998). Purification, product characterization and kinetic properties of soluble wild pear lipoxygenase. Plant Physiol. Biochem., 36:657-663.

Yawer, MA, Ahmed, E, Malik, A, Ashraf, M, Rasool, MA, Afza, N. (2007) New lipoxygenaseinhibiting constituents from Calligonum polygonoids. Chem. Biodivers., 4:1578-1585.

How to cite this article: Shahriar Saeidian, Bahaaldin rashidzadeh, Roza Negahdari. Kinetic Studies with Crude Wild Pear Lipoxygenase at During Ripening and After Storage. International Journal of Advanced Biological and Biomedical Research, 2020, 8(1), 17-28. Link: http://www.ijabbr.com/article 36171.html 